\title{
Exogenous hydrogen sulfide exerts proliferation, anti-apoptosis, migration effects and accelerates cell cycle progression in multiple myeloma cells via activating the Akt pathway
}

\author{
DONG ZHENG $^{1 *}$, ZIANG CHEN $^{1 *}$, JINGFU CHEN $^{2}$, XIAOMIN ZHUANG $^{3}$, JIANQIANG FENG $^{4}$ and JUAN LI ${ }^{1}$ \\ Departments of ${ }^{1}$ Hematology, ${ }^{2}$ Cardiovasology and Cardiac Care Unit (CCU), Huangpu Division, \\ ${ }^{3}$ Endocrinology, The First Affiliated Hospital, Sun Yat-sen University; ${ }^{4}$ Department of Physiology, \\ Zhongshan School of Medicine, Sun Yat-sen University, Guangzhou, Guangdong 510080, P.R. China
}

Received January 16, 2016; Accepted February 24, 2016

DOI: 10.3892/or.2016.5014

\begin{abstract}
Hydrogen sulfide $\left(\mathrm{H}_{2} \mathrm{~S}\right)$, regarded as the third gaseous transmitter, mediates and induces various biological effects. The present study investigated the effects of $\mathrm{H}_{2} \mathrm{~S}$ on multiple myeloma cell progression via amplifying the activation of Akt pathway in multiple myeloma cells. The level of $\mathrm{H}_{2} \mathrm{~S}$ produced in multiple myeloma (MM) patients and healthy subjects was measured using enzyme-linked immunosorbent assay (ELISA). MM cells were treated with $500 \mu \mathrm{mol} / 1 \mathrm{NaHS}$ (a donor of $\mathrm{H}_{2} \mathrm{~S}$ ) for $24 \mathrm{~h}$. The expression levels of phosphorylated-Akt (p-Akt), Bcl-2 and caspase-3 were measured by western blot assay. Cell viability was detected by Cell Counting Kit 8 (CCK-8). The cell cycle was analyzed by flow cytometry. Our results show that the concentration of $\mathrm{H}_{2} \mathrm{~S}$ was higher in $\mathrm{MM}$ patients and that it increased in parallel with disease progression. Treating MM cells with $500 \mu \mathrm{mol} / \mathrm{l} \mathrm{NaHS}$ for $24 \mathrm{~h}$ markedly increased the expression level of Bcl-2 and the activation of $\mathrm{p}$-Akt, however, the expression level of caspase-3 was decreased, cell viability was increased, and cell cycle progression was accelerated in MM cells. NaHS also induced migration in MM cells in transwell migration assay. Furthermore, co-treatment of MM cells with $500 \mu \mathrm{mol} / 1 \mathrm{NaHS}$ and $50 \mu \mathrm{mol} / 1 \mathrm{LY} 294002$ for $24 \mathrm{~h}$ significantly overset these effects. In conclusion, our findings demonstrate that the Akt pathway contributes to NaHS-induced cell proliferation, migration and acceleration of cell cycle progression in MM cells.
\end{abstract}

Correspondence to: Dr Juan Li, Department of Hematology, The First Affiliated Hospital, Sun Yat-sen University, Guangzhou, Guangdong 510080, P.R. China

E-mail: 13719209240@163.com

${ }^{*}$ Contributed equally

Key words: hydrogen sulfide, proliferation, migration, anti-apoptosis, Akt, multiple myeloma cells

\section{Introduction}

Multiple myeloma (MM) is a malignant disorder that is characterized by the proliferation of a single clone of plasma cells, which are derived from B cells in the bone marrow (1). The incidence of MM varies globally from 1 per 100,000 people in China to approximately 4 per 100,000 people in most developed countries (2). Advances in therapies for MM, such as highdose therapy followed by autologous stem cell transplantation (ASCT), have been shown to improve response rates, eventfree survival, and overall survival (3). However, the molecular mechanisms by which the myeloma microenvironment influences myeloma cell survival and its responsiveness to therapy remain unclear. Previous investigations have demonstrated alterations in the phosphatidylinositol 3-kinase (PI3K)/Akt signaling cascades in MM cells and implicated the pathway in clonal expansion $(4,5)$.

Akt is a serine (Ser)/threonine (Thr) protein kinase that resides within the cytosol in a catalytically inactive state in quiescent or serum-starved cells (6). Activated Akt phosphorylates downstream target molecules, including Bcl-2, caspase-9, and $\mathrm{Bad}$, which promote induction of its anti-apoptotic effects (5). The PI3K/Akt pathway is one of many signaling pathways that play oncogenic roles in a wide spectrum of human cancers (7). Several studies have strongly suggested that Akt signaling mediates MM cell resistance to conventional therapeutics, and biologically based treatments targeting Akt may induce anti-MM activity in the bone marrow microenvironment (8). However, the specific role of the activation of Akt pathway in the oncogenic processes involved in multiple myeloma is not completely understood.

Hydrogen sulfide $\left(\mathrm{H}_{2} \mathrm{~S}\right)$, a toxic gas that smells like rotten eggs, forms with nitric oxide (NO) and carbon monoxide (CO) a group of biologically active gases that are termed gasotransmitters or gasomediators $(9,10) \cdot \mathrm{H}_{2} \mathrm{~S}$ is endogenously generated from L-cysteine by pyridoxal-5' phosphate-dependent enzymes, including cystathionine $\beta$-synthase (CBS) and/or cystathionine $\gamma$-lyase (CSE), in mammalian cells (11). Work over the last decade has recognized the importance of endogenously produced $\mathrm{H}_{2} \mathrm{~S}$ in a variety of biological functions in the nervous, cardiovascular, and immune systems $(10,12)$. 
There is currently no information available regarding the effect of exogenous $\mathrm{H}_{2} \mathrm{~S}$ on multiple myeloma or its related mechanisms. The present study is aimed at investigating whether $\mathrm{H}_{2} \mathrm{~S}$ contributes to cancer progress and at exploring whether its effects involve the amplification of the Akt pathway in multiple myeloma cells.

\section{Materials and methods}

Patients. Twenty MM patients (11 males and 9 females) were included in this study. Their median age was 57 years (range: 37-70 years). According to international staging system (ISS), 4 were classified as stage I, 7 as stage II and 9 as stage III. Concerning the types of monoclonal proteins present in the patients, 12 had IgG, 5 had IgA and 3 had light chain disease. Fifteen age- and gender-matched healthy subjects were the control group. This work was performed in accordance with the guidelines of the Declaration of Helsinki. This study was cleared by our Institutional Ethics Review Board for human studies, and all subjects signed an informed consent document. After informed consent was provided, peripheral venous blood was collected in sterile tubes using EDTA as anticoagulant and centrifuged at $1000 \mathrm{~g}$ for $10 \mathrm{~min}$ within $30 \mathrm{~min}$ of collection. Plasma was extracted in the supernatant and stored at $-70^{\circ} \mathrm{C}$ for $\mathrm{H}_{2} \mathrm{~S}$ determination.

Reagents. Sodium hydrosulfide (NaHS) and LY294002 were obtained from Sigma-Aldrich (St. Louis, MO, USA). Freshly made NaHS solution was used as the $\mathrm{H}_{2} \mathrm{~S}$ donor. The Cell Counting Kit 8 (CCK-8) was supplied by Dojindo Laboratories (Kumamoto, Japan). Fetal bovine serum (FBS) and DMEM medium were obtained from Gibco BRL (Grand Island, NY, USA). Anti- phosphorylated-Akt (p-Akt) antibody, and Anti-total Akt (t-Akt) antibody, anti-Bcl-2 antibody and anti-caspase-3 antibody were purchased from Cell Signaling Technology (Danvers, MA, USA).

Cell culture. The human myeloma cell line NCI-H929 was supplied by the Sun Yat-sen University Cancer Center (Guangzhou, Guangdong, China) and maintained in DMEM medium supplemented with $10 \% \mathrm{FBS}, 100 \mu \mathrm{g} / \mathrm{ml}$ streptomycin and $100 \mathrm{IU} / \mathrm{ml}$ penicillin at $37^{\circ} \mathrm{C}$ in a $5 \% \mathrm{CO}_{2}$ incubator. The NCI-H929 cells were treated with $500 \mu \mathrm{mol} / 1 \mathrm{NaHS}$ for $24 \mathrm{~h}$ or co-treated with $500 \mu \mathrm{mol} / 1 \mathrm{NaHS}$ and $50 \mu \mathrm{mol} / 1 \mathrm{LY} 294002$ for $24 \mathrm{~h}$.

Cell proliferation assay. NCI-H929 cells were cultured in 96-well tissue culture plates $\left(2 \times 10^{4}\right.$ cells per well) in DMEM supplemented with $10 \%$ FBS for $24 \mathrm{~h}$. Then, the cells were exposed to different concentrations of NaHS (500 and $1,000 \mu \mathrm{mol} / \mathrm{l})$ for $24 \mathrm{~h}$. Cell proliferation was measured by CCK- 8 assay kit. Briefly, $10 \mu$ l CCK- 8 solution was added to each well, and the plates were incubated for an additional $2 \mathrm{~h}$. Absorbance was measured using a spectrometer at a wave length of $450 \mathrm{~nm}$. The means of the optical density (OD) of three wells in the indicated groups were used to calculate the percentage of cells that were viable according to the formula: cell viability $(\%)=(\mathrm{OD}$ treatment group/OD control group $)$ $\mathrm{x} 100 \%$. The experiments were performed three times.
Cell cycle analysis by flow cytometry. Cells were plated in 6 -well plates at a density of $2 \times 10^{6}$ cells per well and grown in serum-free medium. Then, the cells were exposed to different concentrations of NaHS or co-treated with $500 \mu \mathrm{mol} / 1 \mathrm{NaHS}$ and $50 \mu \mathrm{mol} / 1 \mathrm{LY} 294002$. After $24 \mathrm{~h}$, the cell cycle analysis was performed. The cells were harvested and fixed in $70 \%$ ethanol at $4^{\circ} \mathrm{C}$ overnight. The fixed cells were washed twice with PBS, treated with RNase A $(50 \mu \mathrm{g} / \mathrm{ml})$ for $30 \mathrm{~min}$ at room temperature, and then stained with propidium iodide. The stained cells were examined to analyze for the cell cycle using a Beckman Coulter XL instrument (Beckman Coulter, Brea, CA, USA).

Western blot analysis. As described above, the cells were harvested and lysed using RIPA lysis buffer supplemented with protease inhibitors. Total proteins were extracted and quantified using a bicinchoninic acid (BCA) protein assay kit. Loading buffer was added to the cytosolic extracts and the solution was then boiled for $5 \mathrm{~min}$. The same amount of supernatant was obtained from each sample and fractionated using $10 \%$ sodium dodecyl sulphate-polyacrylamide gel electrophoresis (SDS-PAGE), and the total proteins were then transferred to polyvinylidene difluoride (PVDF) membranes. The membranes were blocked in 5\% fat-free milk in fresh blocking buffer [0.1\% Tween-20 in Tris-buffered saline (TBS-T)] for $60 \mathrm{~min}$ at room temperature. They were then incubated in either anti-t-Akt antibody $(1: 1,000)$, antip-Akt antibody $(1: 1,000)$, anti-Bcl-2 antibody $(1: 1,000)$, or anti-caspase- 3 antibody $(1: 1,000)$ in freshly prepared TBS-T containing $3 \%$ free-fat milk overnight with gentle agitation at $4^{\circ} \mathrm{C}$. The membranes were washed three times for $5 \mathrm{~min}$ each with TBS-T and then incubated with HRP-conjugated goat anti-rabbit secondary antibody $(1: 3,000)$ in TBS-T containing $3 \%$ fat-free milk for $1.5 \mathrm{~h}$ at room temperature. Then, the membranes were washed three times for 5 min each in TBS-T. The immunoreactive proteins were visualized using ECL reagent. To quantify protein expression levels, the X-ray film was scanned and analyzed using ImageJ 1.47 i software. The experiments were performed 3 times.

ELISA assay. The concentrations of $\mathrm{H}_{2} \mathrm{~S}$ in plasma samples were determined using ELISA (Quantikine R\&D System, Minneapolis, MN, USA) according to the manufacturer's instructions. Briefly, these assays involved the application of the quantitative sandwich enzyme immunoassay technique. Monoclonal antibodies that were specific for each assay were pre-coated onto microplates. Standard controls and samples (100 $\mu \mathrm{l}$ of plasma) were pipetted into the wells in duplicate. After $\mathrm{H}_{2} \mathrm{~S}$ was bound and the plates were washed, an enzyme-linked polyclonal antibody that was specific for $\mathrm{H}_{2} \mathrm{~S}$ was added to each well. After the plates were thoroughly washed, a substrate solution was added to the wells, and the color developed in proportion to the amount of $\mathrm{H}_{2} \mathrm{~S}$ that was bound during the first step. The optical density of each well was determined using a microplate reader at $450 \mathrm{~nm}$. The value for the blank was subtracted from both the standard controls and the samples. A standard curve was created by plotting the logarithm of the mean absorbance of each standard versus the logarithm of the known $\mathrm{H}_{2} \mathrm{~S}$ concentration. Concentrations are shown as picograms per milliliter. The experiments were repeated 3 times. 

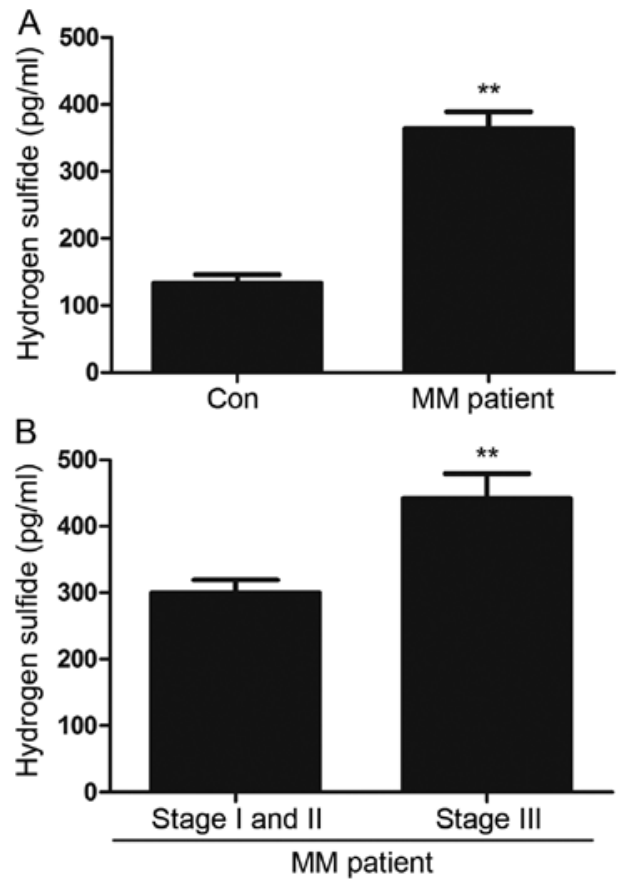

Figure 1. (A) The serum levels of hydrogen sulfide $\left(\mathrm{H}_{2} \mathrm{~S}\right)$ in $\mathrm{MM}$ patient were higher than that in controls. (B) There was significant difference in serum $\mathrm{H}_{2} \mathrm{~S}$ levels between the stage I-II and stage III MM patient groups. The data are presented as the means $\pm \operatorname{SEM}(n=3),{ }^{* *} \mathrm{P}<0.01$. Con, control group; MM patient, multiple myeloma patient group.

Transwell migration assay. Human myeloma cells were harvested and washed twice with PBS. After the cells were washed, $1 \times 10^{5}$ cells were resuspended in $200 \mu 1$ DMEM and added to the upper chamber of the transwell membrane (Transwell Permeable Support with a 5.0- $\mu \mathrm{m}$ polycarbonate membrane, 6.5-mm insert, and 24-well plate; Corning Costar, Tewksbury, MA, USA), and $600 \mu 1$ of $10 \%$ FBS-DMEM was added to each bottom chamber. Four upper chamber conditions were included in the assay: 1) control, 2) NaHS (500 $\mu \mathrm{mol} / \mathrm{l}), 3) \mathrm{NaHS}(500 \mu \mathrm{mol} / \mathrm{l})+\mathrm{LY} 294002(50 \mu \mathrm{mol} / \mathrm{l})$, and 4) LY294002 (50 $\mu \mathrm{mol} / 1)$. After $24 \mathrm{~h}$ of incubation at $37^{\circ} \mathrm{C}$, the cells that had migrated to the lower chambers were counted. Triplicate experiments were performed for each group, and the means and standard deviations were calculated.

Statistical analysis. The results are expressed as mean \pm SD. Differences between groups were analyzed using one-way ANOVA followed by LSD post-hoc comparison tests in SPSS 13.0 (SPSS, Chicago, IL, USA) software. Significance was established at the $\mathrm{P}<0.05$ level.

\section{Results}

Hydrogen sulfide concentration in the serum of MM patients is significantly higher than in healthy controls. All measured parameters were significantly higher in MM patients than in healthy controls. Furthermore, they increased in parallel with disease progression, with higher values observed in more advanced ISS stages. Higher serum levels of hydrogen sulfide were observed in MM patients than in controls, and these levels increased as the disease advanced. Serum $\mathrm{H}_{2} \mathrm{~S}$ concentrations in patients with MM were significantly elevated
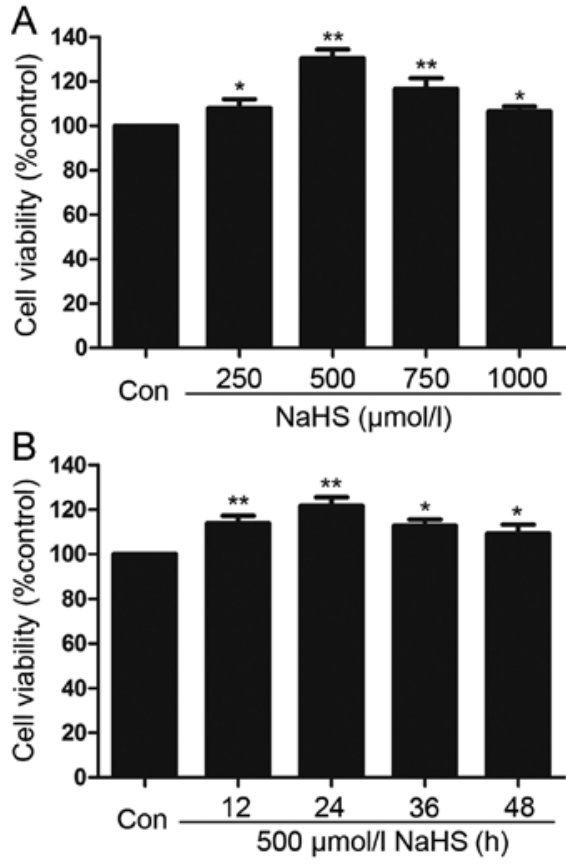

Figure 2. NaHS promotes cell proliferation in myeloma cells. Cell viability was tested by using the Cell Counting Kit (CCK-8). (A) Myeloma cells were treated with different doses of NaHS $(250,500,750$ and 1,000 $\mu \mathrm{mol} / 1)$ for $24 \mathrm{~h}$. (B) Cells were treated with $500 \mu \mathrm{mol} / 1 \mathrm{NaHS}$ for the indicated times $(12,24,36$ and $48 \mathrm{~h})$. The data are shown as the mean \pm SEM $(n=3) .{ }^{*} \mathrm{P}<0.05$, ${ }^{* *} \mathrm{P}<0.01$ compared to the control group. Con, the control group; NaHS, a donor of $\mathrm{H}_{2} \mathrm{~S}$.

compared to the controls $(\mathrm{P}<0.01)$ (Fig. 1A). Furthermore, statistically significant differences were found in the levels of $\mathrm{H}_{2} \mathrm{~S}$ between the stage I-II and stage III MM patient groups $(\mathrm{P}<0.01)$ (Fig. 1B).

NaHS promotes cell proliferation in multiple myeloma cells. To test the effect of exogenous $\mathrm{H}_{2} \mathrm{~S}$ on human myeloma cell proliferation, a dose-response study was performed using varying doses $(250,500,750$ and $1,000 \mu \mathrm{mol} / \mathrm{l})$ of NaHS (a donor of $\mathrm{H}_{2} \mathrm{~S}$ ) for $24 \mathrm{~h}$ to calculate the most effective dose of NaHS (Fig. 2A). The doses of NaHS ranging between 250 and $1,000 \mu \mathrm{mol} / 1$ markedly promoted cell proliferation, leading to an increase in cell viability that reached a peak at $500 \mu \mathrm{mol} / \mathrm{l}$. Therefore, $500 \mu \mathrm{mol} / \mathrm{l} \mathrm{NaHS}$ was used in the subsequent timeresponse study in which we analyzed the impact of different treatment times $(12,24,36$ and 72 h). As shown in Fig. 2B, treatment of myeloma cells with $500 \mu \mathrm{mol} / 1 \mathrm{NaHS}$ for all of the indicated times markedly promoted cell proliferation, which reached a maximal proliferative effect at $24 \mathrm{~h}$. Based on the above results, myeloma cells were treated with $500 \mu \mathrm{mol} / 1$ $\mathrm{NaHS}$ for $24 \mathrm{~h}$ in all of the following experiments.

NaHS accelerates cell cycle progression in multiple myeloma cells. To investigate the effect of exogenous $\mathrm{H}_{2} \mathrm{~S}$ on cell cycle progression in human myeloma cells, effects on the cell cycle were analyzed using flow cytometry. The results showed that cell cycle progress was markedly altered when the cells were treated with NaHS. The results indicated that in myeloma cells, NaHS reduced cell cycle arrest in the G0/G1 phase and increased the proportion of cells in the $\mathrm{S}$ and $\mathrm{G} 2 / \mathrm{M}$ phases (Fig. 3A). 

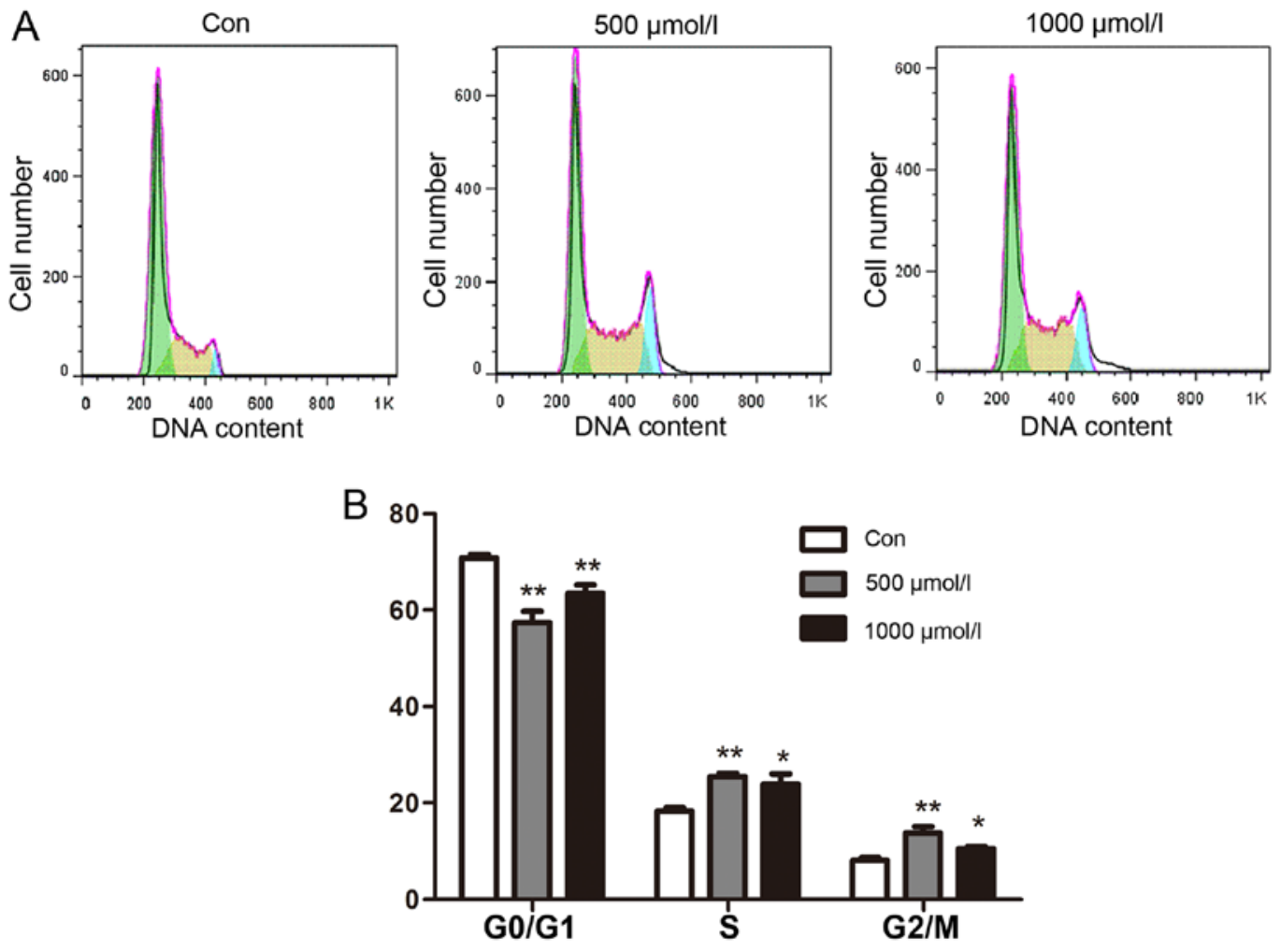

Figure 3. NaHS accelerates cell cycle progression in multiple myeloma cells. (A) Myeloma cells were treated with different doses of NaHS (500 and 1,000 $\mu$ mol/l), harvested at $24 \mathrm{~h}$ and then subjected to flow cytometry to analyze DNA levels and cell cycle progression. (B) The histogram shows the percentage of cells in the different cell cycle phases in cells exposed to NaHS compared to the untreated controls after $24 \mathrm{~h}$. The data are shown as the mean $\pm \mathrm{SEM}(\mathrm{n}=3)$. " $\mathrm{P}<0.05$, ${ }^{* *} \mathrm{P}<0.01$ compared to the corresponding controls.

To compare the experimental results more intuitively, we drew histograms. The percentage of cells in the different cell cycle phases after exposure to NaHS was compared to the corresponding percentage in the untreated controls at the same time point. The results revealed a dose-dependent trend in which the proportion of cells in the G0/G1 phase decreased and the proportion of cells in the $\mathrm{S}$ phase and G2/M phases increased as the NaHS concentration increased. The most obvious change was observed at the $24 \mathrm{~h}$ time point when cells were treated with $500 \mu \mathrm{mol} / 1 \mathrm{NaHS}$ (Fig. 3B).

NaHS amplifies the activation of Akt in multiple myeloma cells. We analyzed the effects of NaHS on the level of Akt phosphorylation. Multiple myeloma cells were exposed to $500 \mu \mathrm{mol} / 1 \mathrm{NaHS}$ for the indicated times $(3,6,9,12$ and $24 \mathrm{~h})$, and the expression level of p-Akt was significantly upregulated, reaching a peak at $24 \mathrm{~h}$ (Fig. $4 \mathrm{~A}$ and $\mathrm{B}$ ).

NaHS reduces the expression of caspase- 3 and upregulates the level of Bcl-2 in multiple myeloma cells. To analyze the effect of NaHS on the expression of caspase-3 and Bcl-2 in multiple myeloma cells, multiple myeloma cells were exposed to $500 \mu \mathrm{mol} / 1 \mathrm{NaHS}$ for different period of time (3, 6, 9, 12 and 24 h). As shown in Fig. 4, NaHS significantly enhanced the expression of Bcl-2, which reached a peak at $9 \mathrm{~h}$, and reduced the expression of caspase- 3 .

LY294002 suppresses NaHS-induced increased cell viability in multiple myeloma cells. Exposing multiple myeloma cells to
$500 \mu \mathrm{mol} / 1 \mathrm{NaHS}$ for $24 \mathrm{~h}$ significantly induced cell proliferation and increased cell viability. However, the increased cell viability was repressed by co-treatment with different doses of LY294002 (a specific inhibitor of the Akt pathway) for 24 h. As shown in Fig. 5, increasing the dose of LY294002 from 1 to $10 \mu \mathrm{mol} / 1$ did not change cell viability. However, increasing the dose of LY294002 from 50 to $200 \mu \mathrm{mol} / 1$ significantly suppressed cell proliferation, with the decrease in cell viability reaching a minimum at $50 \mu \mathrm{mol} / 1$. In accordance with the above results, multiple myeloma cells were co-treated with $500 \mu \mathrm{mol} / 1 \mathrm{NaHS}$ and $50 \mu \mathrm{mol} / 1 \mathrm{LY} 294002$ for $24 \mathrm{~h}$ in all subsequent experiments.

LY294002 reduces the NaHS-induced acceleration of cell cycle progression in multiple myeloma cells. As shown in Fig. 6A-D, multiple myeloma cells were exposed to $500 \mu \mathrm{mol} / \mathrm{l} \mathrm{NaHS}$ for $24 \mathrm{~h}$, the S-phase and G2/M-phase cells were significantly increased. However, the G0/G1-phase population of cells was markedly decreased. Co-treatment of multiple myeloma cells with $500 \mu \mathrm{mol} / 1 \mathrm{NaHS}$ and $50 \mu \mathrm{mol} / 1$ LY294002 for $24 \mathrm{~h}$ substantially depressed the NaHS-induced increase in the proportions of S-phase and G2/M-phase cells and significantly decreased the number of G0/G1-phase cells. Treating the cells with $50 \mu \mathrm{mol} / 1 \mathrm{LY} 294002$ for $24 \mathrm{~h}$ did not alter cell cycle progression.

LY294002 inhibits the NaHS-induced increase in the expression of Bcl-2 and upregulates the NaHS-induced decrease in caspase-3 expression in multiple myeloma cells. As shown 

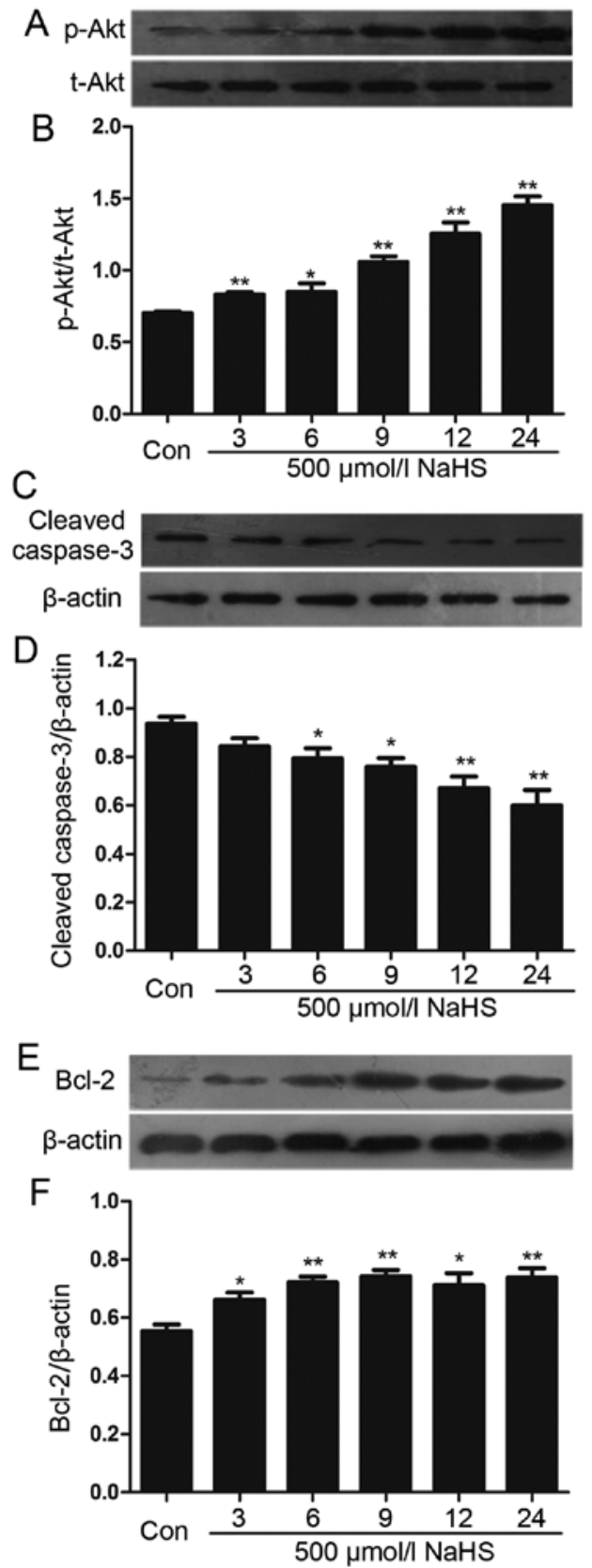

Figure 4. NaHS amplifies the activation of Akt via phosphorylation in myeloma cells. Myeloma cells were exposed to $500 \mu \mathrm{mol} / 1 \mathrm{NaHS}$ for the indicated times $(3,6,9,12$ and $24 \mathrm{~h})$. NaHS reduced the expression of caspase-3 and upregulated the expression of p-Akt and Bcl-2 in myeloma cells. The expression of caspase- 3 and $\mathrm{Bcl}-2$ was measured using western blot analysis (B, D and F). The data shown in (A, C and $\mathrm{E}$ ) were quantified using densitometric analysis in Image $\mathrm{J}$ 1.47. The data are shown as the mean $\pm \mathrm{SEM}$ $(\mathrm{N}=3) .{ }^{*} \mathrm{P}<0.05,{ }^{* *} \mathrm{P}<0.01$ compared to the control group. Con, the control group; NaHS, a donor of $\mathrm{H}_{2} \mathrm{~S}$.

in Fig. 7, multiple myeloma cells were exposed to $500 \mu \mathrm{mol} / 1$ $\mathrm{NaHS}$ for $24 \mathrm{~h}$, and the expression of Bcl-2 was significantly increased. However, the expression of caspase-3 was markedly decreased. Notably, co-treatment of multiple myeloma cells with $500 \mu \mathrm{mol} / 1 \mathrm{NaHS}$ and $50 \mu \mathrm{mol} / 1 \mathrm{LY} 294002$ for $24 \mathrm{~h}$ considerably depressed the NaHS-induced increase in the expression of Bcl-2 while significantly upregulating caspase-3 expression. Treating the cells with $50 \mu \mathrm{mol} / 1 \mathrm{LY} 294002$ for $24 \mathrm{~h}$ did not alter the basal expression levels of Bcl-2 and caspase-3.

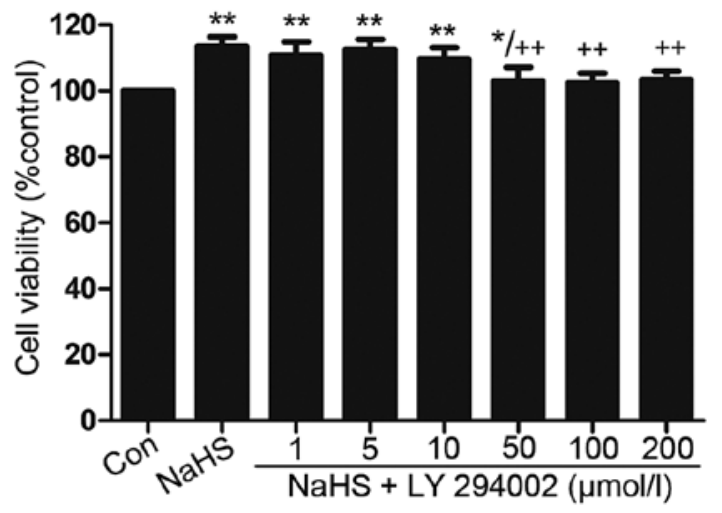

Figure 5. LY294002 reduces NaHS-induced cell proliferation in multiple myeloma cells. Multiple myeloma cells were co-treated with $500 \mu \mathrm{mol} / 1$ NaHS and different doses of LY294002 (1, 5, 10, 50, 100 or $200 \mu \mathrm{mol} / \mathrm{l})$ for $24 \mathrm{~h}$. The data are shown as the mean \pm SEM $(n=3) .{ }^{*} \mathrm{P}<0.05,{ }^{* *} \mathrm{P}<0.01$ compared to the control group. ${ }^{++} \mathrm{P}<0.01$ compared to the NaHS group. Con, the control group; NaHS, a donor of $\mathrm{H}_{2} \mathrm{~S}$; LY294002, a specific inhibitor of the Akt pathway.

LY294002 inhibits NaHS-induced migration in MM cells. In transwell migration assays, the migration rates of MM cells (NCI-H929) toward conditioned medium that was collected from NaHS was higher than the spontaneous migration rate, indicating that NaHS induced migration in MM cells. This process was inhibited by the Akt inhibitor.

LY294002 (Fig. 8). These results show that LY294002 inhibits NaHS-induced migration in MM cells and indicates that the Akt pathway may play an important role in the process of NaHS-induced migration.

\section{Discussion}

$\mathrm{H}_{2} \mathrm{~S}$, the third gaseous transmitter following $\mathrm{NO}$ and $\mathrm{CO}$, modulates a range of cellular and molecular mechanisms. Endogenous $\mathrm{H}_{2} \mathrm{~S}$ in mammalian tissues is mainly synthesized via the metabolism of L-cysteine by the catalysis of two key enzymes, CBS and CSE $(13,14)$. Experiments have shown that plasma or blood $\mathrm{H}_{2} \mathrm{~S}$ concentrations range between 30 and $300 \mu \mathrm{M}$ in humans, depending on the method used for measurement and the age of the donor (15). The role of $\mathrm{H}_{2} \mathrm{~S}$, as a physiological molecule with pleiotropic functions, is becoming increasingly apparent. Specifically, $\mathrm{H}_{2} \mathrm{~S}$ can elicit cardioprotective, inflammation-preventing, anti-proliferative and anti-thrombotic effects $(16,17)$. There is an apparent paradox in the effects of $\mathrm{H}_{2} \mathrm{~S}$ on cancer. Many reports have shown that inhibiting $\mathrm{H}_{2} \mathrm{~S}$ biosynthesis exerts anticancer effects, while other studies have shown that $\mathrm{H}_{2} \mathrm{~S}$ donors of various types exert anticancer actions both in vitro and in vivo (18). In recent years, an increasing number of studies have shown that hydrogen sulfide $\left(\mathrm{H}_{2} \mathrm{~S}\right)$ can mediate pathophysiological processes during cancer cell growth, proliferation, migration, and invasion $(17,19,20)$. Nevertheless, it was shown that $\mathrm{H}_{2} \mathrm{~S}$ exerted potential anticancer effects on gastric cancer cells (21), oral cancer cell lines (22), PLC/PRF/5 hepatoma cells (23), and colon cancer cells (24). Furthermore, an increasing amount of evidence has shown that $\mathrm{H}_{2} \mathrm{~S}$ is involved in pathophysiological processes in tumors. The biological effects of $\mathrm{H}_{2} \mathrm{~S}$ that are relevant to cancer biology include the regulation of vascular 

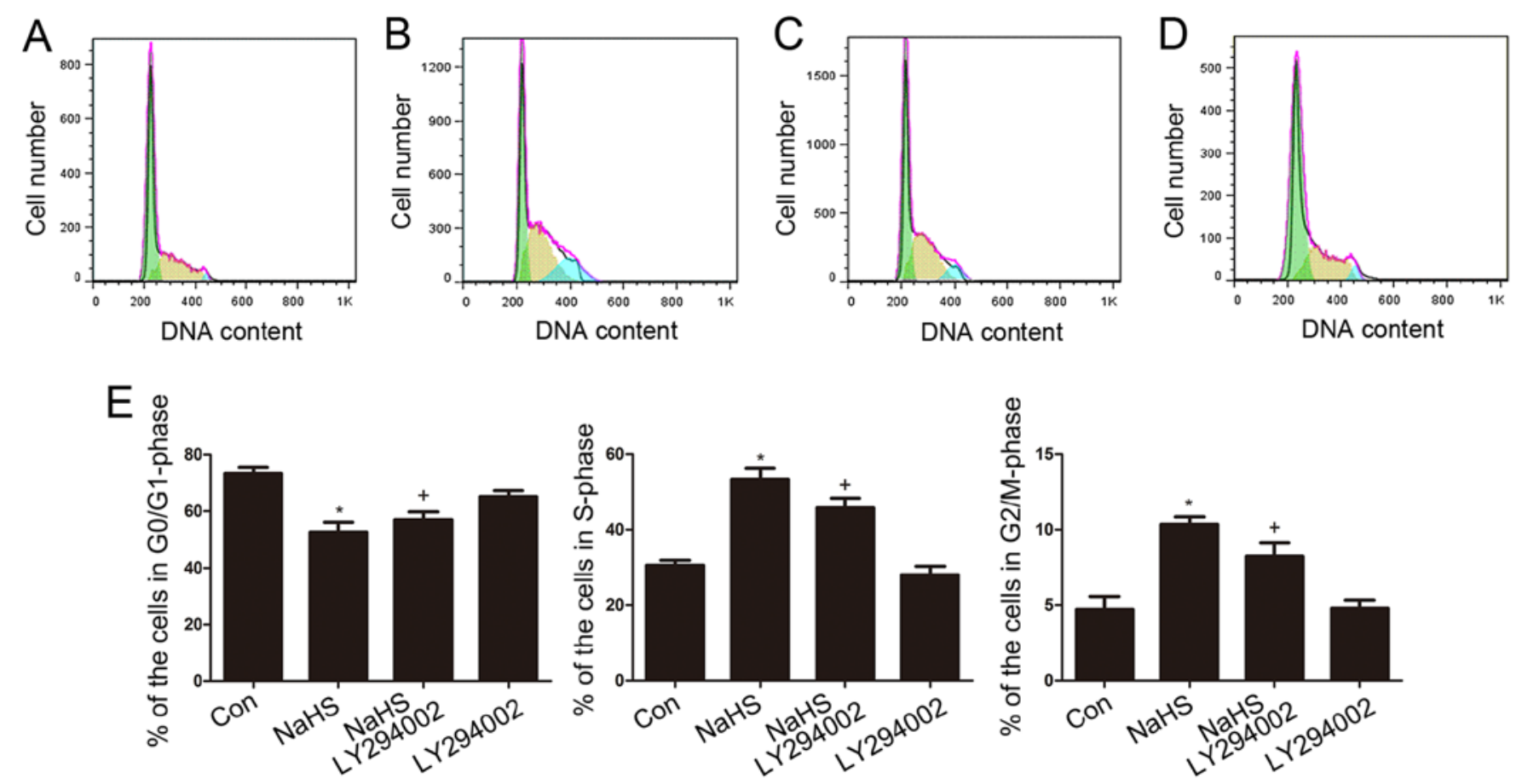

Figure 6. LY294002 reduces the NaHS-induced acceleration in cell cycle progression in multiple myeloma cells. After the indicated treatments (A-D), the cell cycle was analyzed using flow cytometry. (A) Control group. (B) Multiple myeloma cells were exposed to $500 \mu \mathrm{mol} / 1 \mathrm{NaHS}$ for $24 \mathrm{~h}$. (C) Multiple myeloma cells were co-treated with $500 \mu \mathrm{mol} / 1 \mathrm{NaHS}$ and $50 \mu \mathrm{mol} / 1 \mathrm{LY} 294002$ for $24 \mathrm{~h}$. (D) Multiple myeloma cells were treated with $50 \mu \mathrm{mol} / 1 \mathrm{LY} 294002$ for $24 \mathrm{~h}$. (E) The histogram shows the percentage of myeloma cells in the stages of the cell cycle for each of the above treatments. The data are presented as the means \pm SEM $(n=3) . ~ " P<0.01$ compared to the control group; ${ }^{+} \mathrm{P}<0.01$ compared to the NaHS group. Con, the control group; NaHS, a donor of $\mathrm{H}_{2} \mathrm{~S} ; \mathrm{LY} 294002$, a specific inhibitor of the Akt pathway.

A

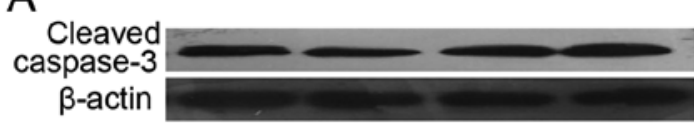

B

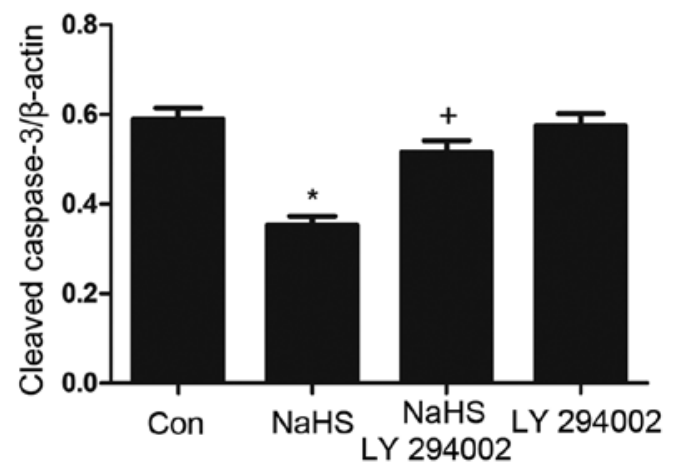

C
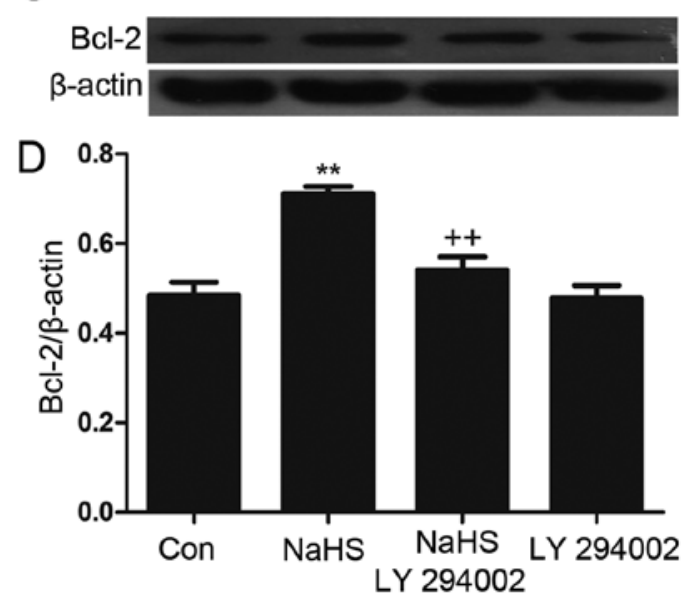

Figure 7. LY294002 inhibits the NaHS-induced increase in the expression of bcl-2 and decrease in the expression of caspase-3 in multiple myeloma cells. Multiple myeloma cells were co-conditioned with $500 \mu \mathrm{mol} / 1 \mathrm{NaHS}$ and $50 \mu \mathrm{mol} / 1 \mathrm{LY} 294002$ for $24 \mathrm{~h}$. (B and D) The expressions of caspase-3 and Bcl-2 were measured using western blot analysis. (A and C) Data were quantified using densitometric analysis in Image $\mathrm{J} 1.47$. The data are presented as the mean \pm SEM $(\mathrm{n}=3) .{ }^{*} \mathrm{P}<0.05$ compared to the control group; ${ }^{* *} \mathrm{P}<0.01$ compared to the control group; ${ }^{+} \mathrm{P}<0.05$ compared to the NaHS group; ${ }^{++} \mathrm{P}<0.01$ compared to the NaHS group. Con, the control group; $\mathrm{NaHS}$, a donor of $\mathrm{H}_{2} \mathrm{~S}$.

functions (vasorelaxation and the stimulation of angiogenesis) (19) and the regulation of intracellular signaling and cell death (during which it acts as a direct and indirect antioxidant and inhibits oxidative damage and cell death in response to diverse stimuli) $(25,26)$.

Based on the results of previous studies, we first collected samples from patients to determine the levels of $\mathrm{H}_{2} \mathrm{~S}$ that are present in the serum. We found some interesting results in this analysis. In our study, serum $\mathrm{H}_{2} \mathrm{~S}$ levels were significantly higher in the multiple myeloma patient group than in the control group. Moreover, they also increased in parallel with disease progression, with higher levels of $\mathrm{H}_{2} \mathrm{~S}$ observed in patients with advanced ISS stages. We hypothesized that this gasotransmitter may be involved in the progression of multiple myeloma. To verify this hypothesis, we treated multiple myeloma cells with NaHS (a donor of $\mathrm{H}_{2} \mathrm{~S}$ that is actively 


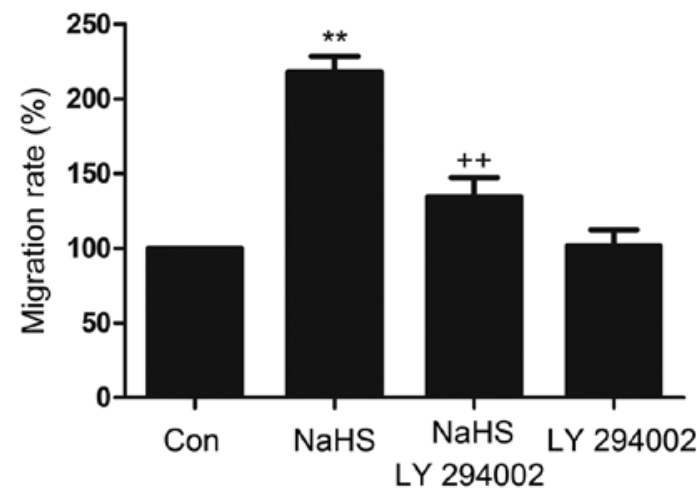

Figure 8. The effects of NaHS, NaHS + LY294002, and LY294002 on the migration of MM cells were analyzed in 96-well migration assays after $24 \mathrm{~h}$ at $37^{\circ} \mathrm{C}$. LY294002 suppressed the NaHS-induced increase in migration in myeloma cells. The data are presented as the mean \pm SEM $(n=3) .{ }^{* *} \mathrm{P}<0.01$ compared to the control group; ${ }^{++} \mathrm{P}<0.01$ compared to the NaHS group. Con, the control group; NaHS, adonor of $\mathrm{H}_{2} \mathrm{~S}$.

being investigated because of the above-described effects of $\mathrm{H}_{2} \mathrm{~S}$ ). Our findings demonstrated that NaHS improved proliferation in multiple myeloma cells when applied at concentrations ranging from 100 to $1,000 \mu \mathrm{mol} / 1$. The optimal concentration of NaHS, at which it induced its maximal effect on proliferation, was $500 \mu \mathrm{mol} / \mathrm{l}$. At this concentration, it led to increased cell viability, indicating that $\mathrm{H}_{2} \mathrm{~S}$ might contribute to multiple myeloma growth. Then, the cells were co-treated with the indicated doses of NaHS for $24 \mathrm{~h}$ to analyze its effects on the cell cycle. The results showed that the proportion of G0/G1-phase cells was significant decreased, while the proportions of S-phase cells and G2/M phase cells were significantly increased. NaHS was therefore found to accelerate cell cycle progression. Treatment of multiple myeloma cells with $500 \mu \mathrm{mol} / 1 \mathrm{NaHS}$ for $24 \mathrm{~h}$ markedly diminished cell apoptosis and decreased the expression of caspase-3, an apoptotic factor. At the same time, the expression of Bcl-2, a protein that protects against apoptosis, was increased. The $\mathrm{Bcl}-2$ protein is a component of a complex signaling system that controls apoptosis, and its overexpression can prevent apoptosis in cells, potentially leading to the continued division of mutated cells lines and eventually to cancer. Additionally, the overexpression of $\mathrm{Bcl}-2$ can contribute to metastasis in certain cancers (27). These results demonstrate that the Bcl-2 pathway is implicated in the NaHS-induced effects on MM cell proliferation, apoptosis and migration. All of these data indicate that $\mathrm{H}_{2} \mathrm{~S}$, when present at a relative high level, might evoke proliferative and anti-apoptotic effects.

Many MM cell lines express high baseline levels of p-Akt. Moreover, Akt is activated in the cells of MM patients (4). The PI3K/Akt pathways plays a crucial role during MM cell growth, survival and drug resistance (28). We sought to explore the mechanism underlying NaHS-induced pro-proliferative, anti-apoptotic, angiogenic, cell cycle progression-accelerating, and pro-migration effects in multiple myeloma cells. Here, we studied the PI3/Akt pathway and found that NaHS markedly increased the phosphorylation of Akt, which may have activated the Akt pathway in multiple myeloma cells. Noteworthy, LY294002, an inhibitor of PI3/Akt, blocked the NaHS-induced activation of PI3/Akt and the NaHS-induced pro-proliferative, anti-apoptotic and pro-migration effects in multiple myeloma cells by decreasing the expression of $\mathrm{Bcl}-2$, increasing the expression of caspase- 3 and reducing the NaHS-induced acceleration of cell cycle progression in multiple myeloma cells. Our data show that NaHS markedly increased cell migration in MM cells. However, the increase in the level of migration was significantly suppressed by co-treating cells with LY 249002. These results suggest that the activation of Akt is necessary for NaHS-induced cell progression in multiple myeloma and the phosphorylation of Akt is required for NaHS-induced cell proliferation. This result is consistent with the results of previous reports that showed that NaHS promotes cancer cell proliferation by up-regulating p-Akt (29).

In summary, $\mathrm{H}_{2} \mathrm{~S}$ induced cell proliferation, inhibited apoptosis, accelerated cell cycle progression, and increased migration in multiple myeloma cells. These effects might be mediated by the activation of the Akt pathway, which leads to the overexpression of $\mathrm{Bcl}-2$, the down-regulation of caspase-3, an increase in cell viability and migration rates, the acceleration of cell cycle progression and a decrease in the number of apoptotic cells. In myeloma cells, $\mathrm{H}_{2} \mathrm{~S}$ is an endogenous tumor-promoting factor that plays a deleterious role in multiple myeloma cell development. The contribution of $\mathrm{H}_{2} \mathrm{~S}$ to myeloma cell growth remains to be further investigated. Further investigations into the biological effects of $\mathrm{H}_{2} \mathrm{~S}$ on multiple myeloma cells may advance our knowledge of this novel gaseous transmitter and lead to a better understanding of multiple myeloma development.

\section{References}

1. Kyle RA and Rajkumar SV: Criteria for diagnosis, staging, risk stratification and response assessment of multiple myeloma. Leukemia 23: 3-9, 2009.

2. Raab MS, Podar K, Breitkreutz I, Richardson PG and Anderson KC: Multiple myeloma. Lancet 374: 324-339, 2009.

3. Hideshima T, Mitsiades C, Tonon G, Richardson PG and Anderson KC: Understanding multiple myeloma pathogenesis in the bone marrow to identify new therapeutic targets. Nat Rev Cancer 7: 585-598, 2007.

4. Hsu J, Shi Y, Krajewski S, Renner S, Fisher M, Reed JC, Franke TF and Lichtenstein A: The AKT kinase is activated in multiple myeloma tumor cells. Blood 98: 2853-2855, 2001.

5. Hideshima T, Nakamura N, Chauhan D and Anderson KC: Biologic sequelae of interleukin-6 induced PI3-K/Akt signaling in multiple myeloma. Oncogene 20: 5991-6000, 2001.

6. Zhang J, Li Y and Shen B: PI3-K/Akt pathway contributes to IL-6-dependent growth of 7TD1 cells. Cancer Cell Int 3: 1-4, 2003.

7. Vivanco I and Sawyers CL: The phosphatidylinositol 3-Kinase AKT pathway in human cancer. Nat Rev Cancer 2: 489-501, 2002.

8. Hsu JH, Shi Y, Hu L, Fisher M, Franke TF and Lichtenstein A: Role of the AKT kinase in expansion of multiple myeloma clones: Effects on cytokine-dependent proliferative and survival responses. Oncogene 21: 1391-1400, 2002.

9. Whiteman M,Le Trionnaire S, Chopra M, Fox B and Whatmore J: Emerging role of hydrogen sulfide in health and disease: Critical appraisal of biomarkers and pharmacological tools. Clin Sci (Lond) 121: 459-488, 2011.

10. Kimura H: Hydrogen sulfide: Its production, release and functions. Amino Acids 41: 113-121, 2011.

11. Szabó C: Hydrogen sulphide and its therapeutic potential. Nat Rev Drug Discov 6: 917-935, 2007.

12. Vandiver M and Snyder SH: Hydrogen sulfide: A gasotransmitter of clinical relevance. J Mol Med Berl 90: 255-263, 2012.

13. Rose P, Moore PK, Ming SH, Nam OC, Armstrong JS and Whiteman M: Hydrogen sulfide protects colon cancer cells from chemopreventative agent beta-phenylethyl isothiocyanate induced apoptosis. World J Gastroenterol 11: 3990-3997, 2005. 
14. Sen N, Paul BD, Gadalla MM, Mustafa AK, Sen T, Xu R, Kim S and Snyder SH: Hydrogen sulfide-linked sulfhydration of NF- $\kappa \mathrm{B}$ mediates its antiapoptotic actions. Mol Cell 45: 13-24, 2012.

15. Whiteman M and Moore PK: Hydrogen sulfide and the vasculature: A novel vasculoprotective entity and regulator of nitric oxide bioavailability? J Cell Mol Med 13: 488-507, 2009.

16. Papapetropoulos A, Pyriochou A, Altaany Z, Yang G, Marazioti A, Zhou Z, Jeschke MG, Branski LK, Herndon DN, Wang R, et al: Hydrogen sulfide is an endogenous stimulator of angiogenesis. Proc Natl Acad Sci USA 106: 21972-21977, 2009.

17. Choi KS, Song H, Kim EH, Choi JH, Hong H, Han YM and Hahm KB: Inhibition of hydrogen sulfide-induced angiogenesis and inflammation in vascular endothelial cells: Potential mechanisms of gastric cancer prevention by Korean red ginseng. J Ginseng Res 36: 135-145, 2012.

18. Hellmich MR, Coletta C, Chao C and Szabo C: The therapeutic potential of cystathionine $\beta$-synthetase/hydrogen sulfide inhibition in cancer. Antioxid Redox Signal 22: 424-448, 2015.

19. Szabó C and Papapetropoulos A: Hydrogen sulphide and angiogenesis: Mechanisms and applications. Br J Pharmacol 164: 853-865, 2011.

20. Attene-Ramos MS, Wagner ED, Plewa MJ and Gaskins HR Evidence that hydrogen sulfide is a genotoxic agent. Mol Cancer Res 4: 9-14, 2006.

21. Zhang L, Qi Q, Yang J, Sun D, Li C, Xue Y, Jiang Q, Tian Y, Xu C and Wang R: An anticancer role of hydrogen sulfide in human gastric cancer cells. Oxid Med Cell Longev 2015: 636410, 2015.
22. Murata T, Sato T, Kamoda T, Moriyama H, Kumazawa Y and Hanada N: Differential susceptibility to hydrogen sulfide-induced apoptosis between PHLDA1-overexpressing oral cancer cell lines and oral keratinocytes: Role of PHLDA1 as an apoptosis suppressor. Exp Cell Res 320: 247-257, 2014.

23. Zhen Y, Pan W, Hu F, Wu H, Feng J, Zhang Y and Chen J: Exogenous hydrogen sulfide exerts proliferation/anti-apoptosis/ angiogenesis/migration effects via amplifying the activation of $\mathrm{NF}-\kappa \mathrm{B}$ pathway in PLC/PRF/5 hepatoma cells. Int J Oncol 46: 2194-2204, 2015.

24. Kodela R, Nath N, Chattopadhyay M, Nesbitt DE, VelázquezMartínez CA and Kashfi K: Hydrogen sulfide-releasing naproxen suppresses colon cancer cell growth and inhibits $\mathrm{NF}-\kappa \mathrm{B}$ signaling. Drug Des Devel Ther 9: 4873-4882, 2015.

25. Kolluru GK, Shen X, Bir SC and Kevil CG: Hydrogen sulfide chemical biology: Pathophysiological roles and detection. Nitric Oxide 35: 5-20, 2013.

26. Wang R: Physiological implications of hydrogen sulfide: A whiff exploration that blossomed. Physiol Rev 92: 791-896, 2012.

27. Fernández Y, Gu B, Martínez A, Torregrosa A and Sierra A: Inhibition of apoptosis in human breast cancer cells: Role in tumor progression to the metastatic state. Int J Cancer 101: 317-326, 2002.

28. Younes H, Leleu X, Hatjiharissi E, Moreau AS, Hideshima T, Richardson P, Anderson KC and Ghobrial IM: Targeting the phosphatidylinositol 3-kinase pathway in multiple myeloma. Clin Cancer Res 13: 3771-3775, 2007.

29. Cai WJ, Wang MJ, Ju LH, Wang C and Zhu YC: Hydrogen sulfide induces human colon cancer cell proliferation: Role of Akt, ERK and p21. Cell Biol Int 34: 565-572, 2010. 